\title{
Distribution of Pests on Vitis riparia in Sandy Soils of the South-Western Ontario
}

\author{
Alireza Rahemi ${ }^{1}$, Adam Dale ${ }^{1}$, Helen Fisher ${ }^{1}$, John Kelly ${ }^{2}$, Toktam Taghavi ${ }^{1}$, Carol Singleton ${ }^{1} \&$ \\ Adam Bonnycastle ${ }^{3}$ \\ ${ }^{1}$ Department of Plant Agriculture, University of Guelph, Canada \\ ${ }^{2}$ KeliRo Company Inc., Canada \\ ${ }^{3}$ Department of Geography, University of Guelph, Canada \\ Correspondence: Alireza Rahemi, Simcoe Research Station, University of Guelph, Simcoe, ON, N3Y 4N5, \\ Canada. Tel: 1-519-426-7127, Ext. 334. E-mail: rahemia@uoguelph.ca; a_rahemi@yahoo.com
}

Received: November 11, 2014

doi:10.5539/jps.v4n1p21
Accepted: December 14, 2014 Online Published: December 20, 2014

URL: http://dx.doi.org/10.5539/jps.v4n1p21

\begin{abstract}
Vitis riparia (Michaux) is native to North America and tolerates the local weather and soil conditions of south-western Ontario in Canada. A survey was done on V. riparia to elicit the distribution of pests on the species in central south-western Ontario. Eight hundred and forty four genotypes of $V$. riparia were observed throughout the sandy soils of five counties in Ontario (Brant, Elgin, Middlesex, Norfolk and Oxford). The location of the selected vines was labeled in the Geographic Information System (GIS). The ArcGIS program was used to make maps of the distribution of the wild grape pests, Phylloxera, Japanese beetle, Filbert gallmaker, Cane Filbert gallmaker, Tumid Filbert gallmaker and Tube Filbert gallmaker midges in those areas. The results show that the density of pests on V. riparia is more severe in some areas than others. Phylloxera and Japanese beetle were the major pests observed. Phylloxera was most prevalent and Japanese beetle least prevalent in Elgin County. The gallmaker midges were found in low densities throughout the area. The distribution of Phylloxera could be related to the soil type, and the distribution of Japanese beetle and Tumid gall midge to the land use. With Phylloxera, it appears that they prefer poor drainage soils which do not dry out readily. Whereas, Japanese beetle and Tumid gall midge prefer undisturbed soils where they can overwinter successfully.
\end{abstract}

Keywords: phylloxera, japanese beetle, filbert gallmaker midge, cane gallmaker midge, tumid gallmaker midge, tube gallmaker midge, ArcGIS

\section{Introduction}

The River Bank Grape or Frost Grape (Vitis riparia Michaux) is a dioecious wild grape (Kevan et al., 1984) native to North America that is found throughout Nova Scotia, New Brunswick, Quebec, Ontario and Manitoba in Canada (Darbyshire, 2003).

In Ontario, V. riparia is a host for many pests, such as Phylloxera (Daktulosphaira vitifoliae Fitch), Japanese beetle (Popillia japonica Newman), Filbert gallmaker midge (Schizomyia coryloides Walsh and Riley), Cane gallmaker midge (Ampeloglypter sesostris LeConte), Tumid gallmaker midge (Janetiella brevicauda Felt.-Johnson) and Tube gallmaker midge (Cecidomyia viticola Osten-Sacken).

Phylloxera is an endemic pest in eastern North America and attacks both wild and cultivated grapes. The root system of $V$. riparia is highly resistant to Phylloxera, while the leaves often carry the galls (Whiting, 2003). Root infestations in grapes are very damaging because the galls disrupt the vascular system of the roots which causes root decay in commercial vineyards, whereas leaf galls rarely cause economic damage. Previous reports have suggested that Phylloxera is less prevalent on sandy soils and usually prefers heavy soils because the fine texture soils cracked on drying, and these openings allow the insects to crawl in and infest the root system (Lowery, 2010). Japanese beetle is a common pest of 300 plant species, including many fruit trees and grapevines. Also, $V$. riparia has been used to monitor the Japanese beetle populations (Kessel, 1997). Japanese beetle larvae over winter in the soil, and the adults emerge in the spring to feed on foliage. In contrast to Phylloxera, Japanese beetle larval density is greatest in sandy soils (Szendrei \& Isaacs, 2005), but a heavy rain can soften hard clay soils to allow Japanese beetle adults to emerge (Blackwelder, 2009). 
Numerous species of gall midges attack grapes. Filbert gall which is caused by the gallmaker midge, rarely harm common grapes unless present in large number (Vineyard IPM Scouting Report, 2010). Cane gall also caused by a midge is a very minor pest of common grapes. The Cane gallmaker overwinters as the adult stage in debris on the ground (Wold-Burkness, 2012a). Tumid gall, another midge which lay eggs within the unfolding bud or shoot tips. Fully developed larvae exit the gall and drop to the soil where they pupate. Midges (adults) are produced from one to three generations per year (Wold-Burkness, 2012b). Tube gall, also caused by midges, is neither very common nor harmful to vineyards.

In order to identify the distribution of the major pest species of $V$. riparia in south-western Ontario, $V$. riparia genotypes were surveyed with the hypothesis that the genotypes have equal susceptibility to pests and diseases throughout the range.

\section{Materials and Methods}

Eight hundred and forty-four genotypes of Vitis riparia were observed throughout the sandy soils of five counties (Brant, Elgin, Middlesex, Norfolk and Oxford) in south-western Ontario between June 19 and October 16, 2012 (Table 1).

The collection sites were selected from the Agriculture Canada soil maps (Soil associations of sothern Ontario, 1964). The locations of the vines were identified using GPS (Garmin, $\left.\operatorname{Dakota}^{\mathrm{TM}} 20\right)$.

Most samples were selected from Norfolk County (72.2\%), and the least from Middlesex (1.7\%). Latitude ranged from $42^{\circ} 17^{\prime} 24^{\prime \prime} \mathrm{N}$ in Glasgow, Elgin County to $43^{\circ} 06^{\prime} 36^{\prime \prime} \mathrm{N}$ in Paris, Brant County. Longitude ranged from $80^{\circ} 07^{\prime} 12^{\prime \prime} \mathrm{W}$ in Port Dover, Norfolk County to $81^{\circ} 28^{\prime} 48^{\prime \prime} \mathrm{W}$ in New Bury, Middlesex County (Table 1).

Table 1. The number of samples of Vitis riparia surveyed and their percentage, and the minimum and maximum latitude and longitude of the samples in five counties in central south-western Ontario

\begin{tabular}{lllllll}
\hline \multirow{2}{*}{ County } & Samples & \multicolumn{3}{l}{ Latitude (North) } & \multicolumn{2}{l}{ Longitude (West) } \\
\cline { 2 - 7 } & Numbers & Percent & Minimum & Maximum & Minimum & Maximum \\
\hline Norfolk & 609 & 72.2 & $42^{\circ} 21^{\prime} 00^{\prime \prime}$ & $43^{\circ} 00^{\prime} 36^{\prime \prime}$ & $80^{\circ} 07^{\prime} 12^{\prime \prime}$ & $80^{\circ} 26^{\prime} 24^{\prime \prime}$ \\
Elgin & 125 & 14.8 & $42^{\circ} 17^{\prime} 24^{\prime \prime}$ & $42^{\circ} 30^{\prime} 36^{\prime \prime}$ & $81^{\circ} 21^{\prime} 36^{\prime \prime}$ & $81^{\circ} 24^{\prime} 00^{\prime \prime}$ \\
Brant & 65 & 7.7 & $43^{\circ} 00^{\prime} 00^{\prime \prime}$ & $43^{\circ} 06^{\prime} 36^{\prime \prime}$ & $80^{\circ} 09^{\prime} 00^{\prime \prime}$ & $80^{\circ} 20^{\prime} 24^{\prime \prime}$ \\
Oxford & 31 & 3.7 & $42^{\circ} 30^{\prime} 00^{\prime \prime}$ & $43^{\circ} 06^{\prime} 00^{\prime \prime}$ & $80^{\circ} 12^{\prime} 00^{\prime \prime}$ & $80^{\circ} 34^{\prime} 12^{\prime \prime}$ \\
Middlesex & 14 & 1.7 & $42^{\circ} 23^{\prime} 60^{\prime \prime}$ & $42^{\circ} 36^{\prime} 00^{\prime \prime}$ & $80^{\circ} 34^{\prime} 12^{\prime \prime}$ & $81^{\circ} 28^{\prime} 48^{\prime \prime}$ \\
\hline
\end{tabular}

Twenty, cuttings of each genotype were collected. Each cutting had 3-4 nodes and each node had a leaf present. Each leaf was scored for the presence of the Phylloxera gall, Filbert gall, Cane gall, and Tumid gall, and either the presence of Japanese beetle or leaf damage caused by the beetle. Also, each genotype was scored for the presence or absence of hairs on the petioles.

The location of surveyed vines (Figure 1) and the presence or absence of each pest species were entered into ArcGIS (10.2) software (ArcGis for desktop, 2013) and maps were made.

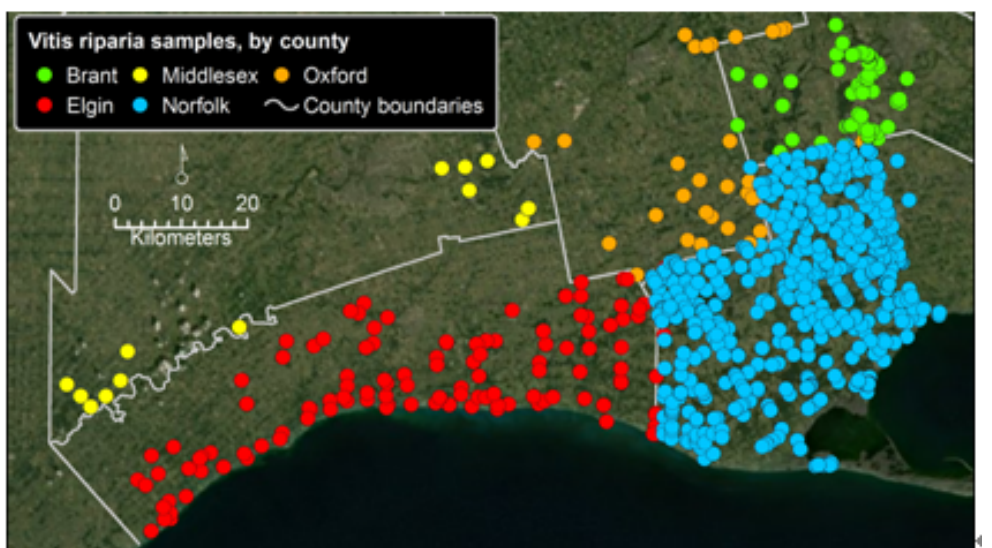

Figure 1. The distribution of the Vitis riparia samples collected in five counties in central south-western Ontario (ArcGIS) 
The presence of petiole hairs was compared with the presence of individual pests using Proc. GLM (SAS. Institute, Version 9.2).

\section{Results}

Only Phylloxera and Japanese beetle were widespread (Table 2). The other four pests were found at less than 5\% of the sites. The highest proportion of genotypes infected by Phylloxera occurred in Elgin County, whereas, it had the lowest proportion of genotypes infected with Japanese beetle.

Table 2. The distribution of six pests of Vitis riparia by percentage and number in five counties in central south-western Ontario

\begin{tabular}{llllllll}
\hline County & $\begin{array}{l}\text { Genotypes } \\
\text { collected }\end{array}$ & Phylloxera & $\begin{array}{l}\text { Japanese } \\
\text { beetle }\end{array}$ & $\begin{array}{l}\text { Filbert } \\
\text { gall }\end{array}$ & $\begin{array}{l}\text { Cane } \\
\text { gall }\end{array}$ & $\begin{array}{c}\text { Tumid } \\
\text { gall }\end{array}$ & $\begin{array}{c}\text { Tube } \\
\text { gall }\end{array}$ \\
\hline Percentage & & & & & & & \\
\hline Elgin & 14.8 & 47.2 & 8.8 & 9.6 & 8.0 & 4.8 & 1.6 \\
Oxford & 3.7 & 35.5 & 22.6 & 12.9 & 9.7 & 12.9 & 0.0 \\
Norfolk & 72.2 & 34.3 & 19.1 & 3.1 & 2.3 & 2.3 & 0.3 \\
Brant & 7.7 & 21.5 & 38.5 & 4.6 & 4.6 & 0.0 & 0.0 \\
Middlesex & 1.7 & 7.1 & 14.3 & 0.0 & 0.0 & 0.0 & 7.1 \\
Average & - & 34.8 & 19.1 & 4.5 & 3.6 & 2.8 & 0.6 \\
\hline Number & & & & & & & \\
\hline Elgin & 125 & 59 & 11 & 12 & 10 & 6 & 2 \\
Oxford & 31 & 11 & 7 & 4 & 3 & 4 & 0 \\
Norfolk & 609 & 209 & 116 & 19 & 14 & 14 & 2 \\
Brant & 65 & 14 & 25 & 3 & 3 & 0 & 0 \\
Middlesex & 14 & 1 & 2 & 0 & 0 & 0 & 1 \\
Total & 844 & 294 & 161 & 38 & 30 & 24 & 5 \\
\hline
\end{tabular}

For Phylloxera, approximately one third of the genotypes were infected, with the highest infection (47.2\%) in Elgin and lowest (7.1\%) in Middlesex Counties (Table 2, Figure 2). Also, 57\% of the infected genotypes had glabrous to slightly pubescent petioles (glabrous to slightly pubescent petioles: pubescent, 161:124, $P=0.006$ ).

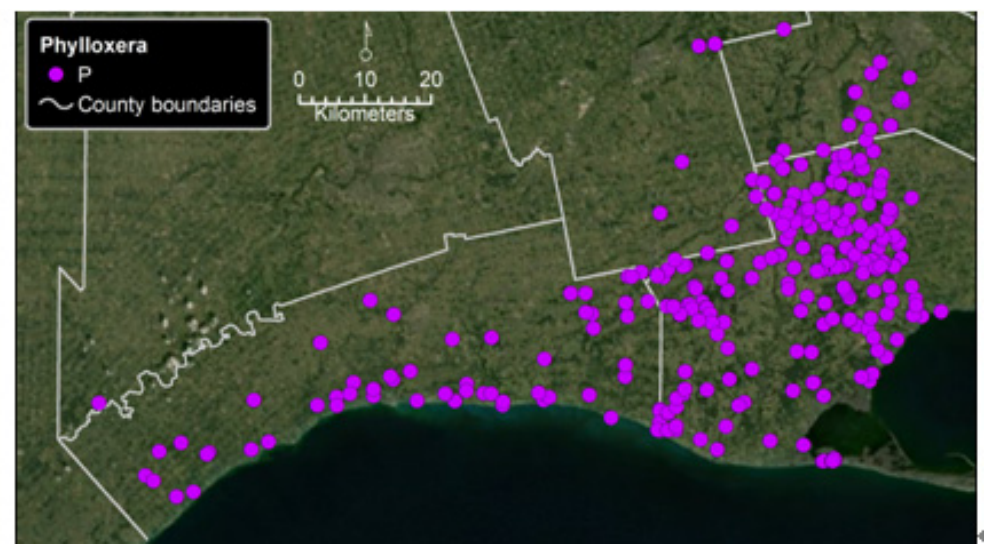

Figure 2. Distribution of Phylloxera on leaves of Vitis riparia in central south-western Ontario

For Japanese beetle approximately one fifth of the genotypes were infected. The most of these occurred in Norfolk and south Brant, with the small concentration around Port Stanley in Elgin County (Table 2, Figure 3). 


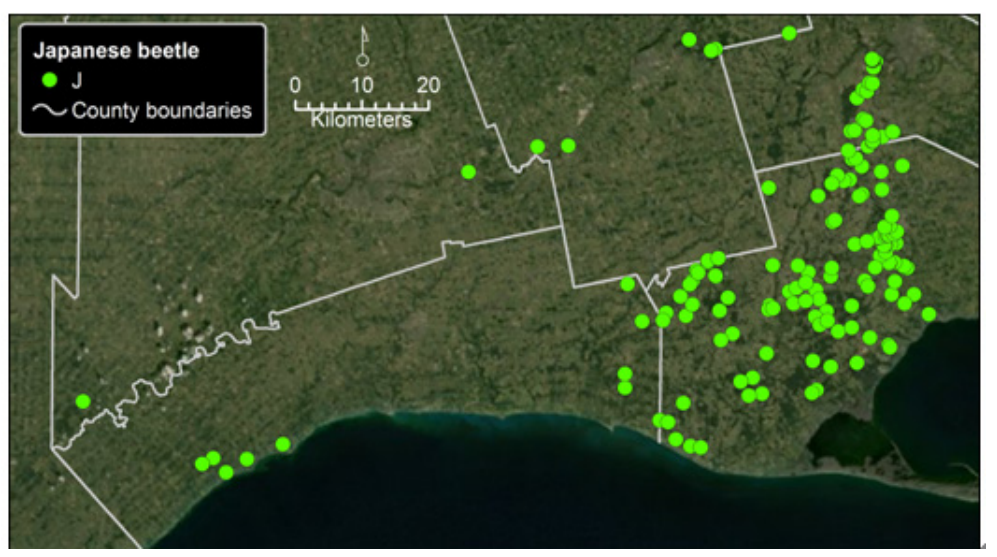

Figure 3. Distribution of Japanese beetle on leaves of Vitis riparia in central south-western Ontario

Filbert gall and Cane gall midges occurred on a low proportion of the genotypes uniformly throughout the area (Table 2, Figure 4 and 5). Tumid gall midges also occurred in low proportion but towards the east part of the area (Figure 6). Tube gall midges were observed on only four genotypes throughout the area.

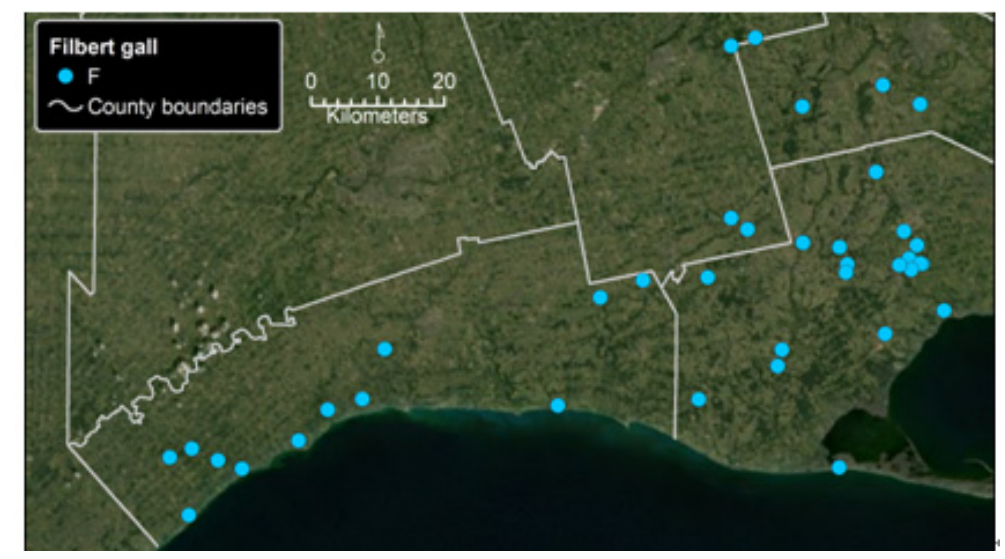

Figure 4. Distribution of Filbert gall on leaves of Vitis riparia in central south-western Ontario

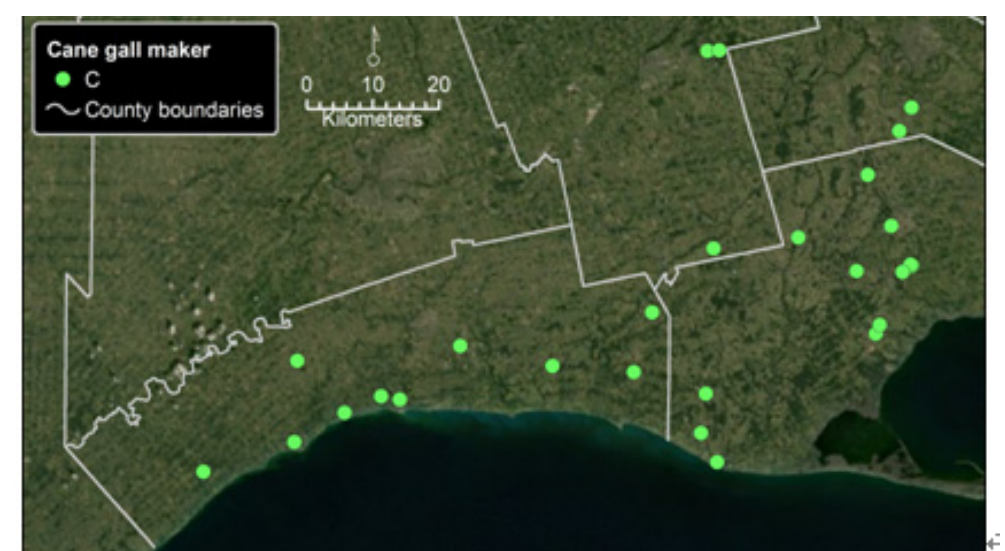

Figure 5. Distribution of Cane gall on leaves of Vitis riparia in central south-western Ontario 


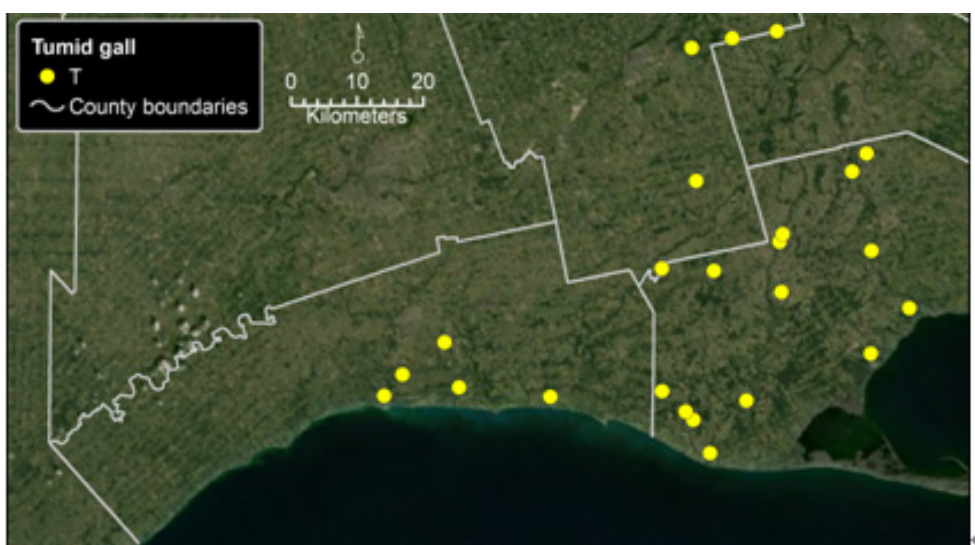

Figure 6. Distribution of Tumid gall on leaves of Vitis riparia in central south-western Ontario

\section{Discussion}

The distribution of Phylloxera, Japanese beetle and Tumid gall varied across central south western Ontario. Japanese beetle and Tumid gall more prevalent in the eastern part of the region whereas Phylloxera was more present in the south of Elgin County.

The complete life cycle of Phylloxera (leaf feeding and gall producing form, gallicole) occurs on $V$. labrusca and $V$. aestivalis, but has not been found on V. riparia (Skinkis et al., 2009). However, Whiting (2003) has mentioned that, while the root system of $V$. riparia is highly resistant to Phylloxera, but the leaves often carry the galls (Whiting, 2003). Leaf galling, if severe, reduces the photosynthetic ability of the vine, but generally is not of major concern unless there are large numbers of galls per leaf (Skinkis et al., 2009).

Phylloxera is not considered a pest on sandy soils, but is often found on vines growing in poor soils because their impact is greater on these vines than on vigorously growing vines (Lowery, 2010). In our survey the soils in the eastern counties of Norfolk and southern Brant are mainly sandy loam with good drainage whereas soils in Elgin are mainly imperfect or with poor drainage (Soil associations of sothern Ontario, 1964). This may have influenced the Phylloxera distribution, as the drainage of the soil may affect their life cycle.

In recent years, the population of Japanese beetle in Ontario has increased because it has become established in some areas of Ontario (Charbonneau \& Sears, 2009). Japanese beetle larvae develop in the soil and the females prefer moist soils to allow them to emerge and lay their eggs in. Also, they are more prevalent in sandy, sandy loam and loamy sand (Thomas, 1925).

The distribution of Japanese beetles maybe related to the land use in the different counties. In the east (Norfolk and southern Brant) there are more horticultural crops, conservation areas and forests, where the soil is relatively undisturbed. Norfolk has the highest percentage of forested land in south-western Ontario (estimated at around 27\%) (Solymár et al., 2008).

Whereas, in Elgin County there are large areas of annual field crops where the soil is cultivated. Hence, this activity may mean that the larvae do not overwinter in those areas.

The distribution of Tumid gall midge may be related to the same factors that affect the Japanese beetle. Tumid gall eggs are laid on the leaves; the larvae develop on the leaves then drop to the ground where they pupate (Wold-Burkness, 2012b).

In conclusion, the survey suggests that the distribution of Phylloxera could be related to the soil type, and the distribution of Japanese beetle and Tumid gall midge to the land use.

With Phylloxera, it appears that they prefer poor drainage soils which do not dry out readily. Whereas, Japanese beetle and Tumid gall midge prefer undisturbed soils where they can overwinter successfully.

\section{Acknowledgement}

Investment in this project has been provided by Agriculture and Agri-Food Canada through the Canadian Agricultural Adaptation Program (CAAP). In Ontario, this program is delivered by the Agricultural Adaptation Council. The authors also thank Ontario South Coast Wineries and Growers Association (OSCWGA) for supporting of this project. 


\section{References}

ArcGis for desktop. (2013). http://www.esri.com/software/arcgis/arcgis-for-desktop/whats-coming/features

Blackwelder, D. (2009). Japanese beetles are staging their annual invasion. Salisbury Post, North Carolina.

Charbonneau, P., \& Sears, M. K. (2009). Grubs in Lawns, Ontario Ministry of agriculture, food and rural affairs. Retrieved from http://www.omafra.gov.on.ca/english/crops/facts/08-023w.htm

Darbyshire, S. J. (2003). Inventory of Canadian Agricultural Weeds (p. 369). National Library of Canada Cataloguing in Publication.

Kessel, C. (1997). Japanese Beetles in Nursery and Turf, Ontario Ministry of agriculture, food and rural affairs. Retrieved from http://www.omafra.gov.on.ca/english/crops/facts/92-105.htm

Kevan, P. G., Longaria, R. W., Randym, N. D., \& Gadaws, M. (1985). Dioecy and pollen dimorphism in Vitis riparia (Vitaceae). Canadian Journal of Botany, 63, 2263-2267. http://dx.doi.org/10.1139/b85-321

Lowery, T. (2010). Grape Phylloxera, Ministry of Agriculture, British Columbia. Retrieved from http://www.agf.gov.bc.ca/cropprot/grapeipm/phylloxera.htm

Rahemi, A., \& Dale, A. (2014). Native Vitis species on Ontario, Canada. 1st International symposium on grapevine roots, Rauscedo, (Acta Horticulturae: Accepted Sep 30, 2014).

SAS. Institute. Version 9.2. (2001). SAS/STAT Software. Cary, NC.

Skinkis, P., Walton, V., \& Kaiser, V. (2009). Grape Phylloxera: Biology and management in the Pacific Northwest, Oregon State University, Extension Service, QEC 1463-E, p. 25.

Snyder, E. (1937). Grape development and improvement, USDA Yearbook of Agriculture, p. 634.

Soil associations of southern Ontario. (1964). Retrieved from http://www.sis.agr.gc.ca/cansis/publications/surveys/on/on30/index.html

Solymár B., Kanter, M., \& May, N. (2008). Caring for nature in Norfolk Landowner Action in Carolinian Canada (p. 8), Carolinian Canada Coalition.

Szendrei, Z., \& Isaacs, R. (2005). Do plant cues influence the oviposition behavior of Japanese beetles. The Netherlands Entomological Society. Entomologia Experimentalis et Applicata, 117, 165-174. http://dx.doi.org/10.1111/j.1570-7458.2005.00346.x

Thomas, C. A. (1925). Observations on the Life History of Popillia Japonica Newm. Journal of Economic Entomology, 18, 357-361.

Vineyard IPM Scouting Report. (2010). Agricultural Research Station Sturgeon Bay, WI. Retrieved from http://door.uwex. edu/files/2010/10/ipmreportweek6710.pdf

Whiting, J. (2003). Selection of grapevine rootstocks and clones for Greater Victoria (p. 36). Department of Primary Industries.

Wold-Burkness, S. (2012a). Grape Cane Gallmaker, University of Minnesota. Retrieved from http://fruit.cfans.umn. edu/files/2012/08/gallmaker.pdf

Wold-Burkness, S. (2012b). Grape Tumid Gallmaker, University of Minnesota. Retrieved from http://fruit.cfans.umn. edu/files/2012/08/tumid.pdf

\section{Copyrights}

Copyright for this article is retained by the author(s), with first publication rights granted to the journal.

This is an open-access article distributed under the terms and conditions of the Creative Commons Attribution license (http://creativecommons.org/licenses/by/3.0/). 